\title{
MENINGKATKAN MOTIVASI BELAJAR BACA TULIS AL QUR'AN DENGAN METODE QUANTUM TEACHING
}

\author{
Badiatul Hikmah \\ STIT Muhammadiyah Bangil
}

\begin{abstract}
Studi this gets beginning of its low motivate and Reading and Writing studying achievement Al Qur'an (BTQ) educative participant SDN Watuagung. It happens because of learning method that applied by reducing paying attention participant trend is taught. Its implication make passive educative participant, causes low spirit their the capturer image be learning always chanted, pall, and achievement that is reached for really lets down, evenless if concerned by participant grasp is taught with tutorial material. To settle about problem in Al Qur'an Reading and Writing learning (BTQ) upon, therefore found one method which can increase participant studying enthusiasm is taught, involving alae educative participant active, and can increase ability and participant studying achievement is taught, which is method Quantum Teaching. One that differentiate this method with method conventional are principle study to become participant belonging is taught, educative participant as sentral studies, participant educativing to empower VAK'S potency (Visual, Auditorial and Kinestetik) to build and gives based science mean its experience correspond to konstruktivis humanistis's paradigm, be educator just personation "fasilitator and condition provider" so learning process can happen. Participant motivation teaches to be said increases, evident gets to increase participant studying motivation is taught because the importance for variation, appreciation, aspiration or aspiration have can increase motivation or studying spirit in get learning In Other Words educative participant will be motivated for studying more energetic be, most more if propped by method Quantum Teaching one that "notabene" can make easy educative participant in accept study material insignificantly and feeling secure deep accept that study, learned achievement to be said worked up if get with attention been proven, and oldster response and environmentally momentous society in increasing achievement studies educative participant, as difficult as whatever a material or study material, will easy feel if did by pleasing and situation taste that agreeable.
\end{abstract}

Keywords: Quantum Taching's method, Learned motivation

\section{Pendahuluan}

Kegiatan pembelajaran adalah suatu kegiatan yang bernilai edukatif, yang terjadi antara guru dengan peserta didik. Dikatakan demikian karena kegiatan pembelajaran yang dilakukan diarahkan untuk mencapai tujuan tertentu yang 
telah dirumuskan sebelum pembelajaran. Guru dengan sadar merencanakan kegiatan pembelajaran secara sistematis dengan memanfaatkan segala sesuatunya guna tercapai tujuan yang diharapkan. Harapan yang tidak pernah sirna dan selalu menjadi tuntutan guru adalah bagaimana bahan pelajaran yang disampaikan dapat dikuasai oleh peserta didik secara tuntas. Ini merupakan masalah yang cukup sulit yang dirasakan guru. Kesulitan itu dikarenakan metode pembelajaran yang diterapkan kurang memperhatikan kecenderungan peserta didik. Sebagai obyek dan subyek pembelajaran peserta didik bukan hanya sebagai individu dengan segala keunikannya, tetapi mereka juga sebagai mahluk sosial dengan latar belakang yang berbeda. Setidaknya ada tiga aspek yang membedakan peserta didik dengan peserta didik lainnya, yaitu aspek intelektual, psikologis dan biologis (Zain: 2010).

Sering kita lihat dari hasil pembelajaran Baca Tulis Al-Qur'an (BTQ) di Sekolah Dasar adalah ketidakmampuan peserta didik menghubungkan materi yang dipelajari dengan bagaimana pengetahuan itu diamalkan dalam kehidupan sehari-hari. Materi yang diperoleh peserta didik di Sekolah Dasar, sebagian besar hanya hafalan dengan tingkat pemahaman yang rendah. Pembelajaran yang dikembangkan hanya masih menekankan transformasi keilmuan dan terfokus pada pengayaan pengetahuan (kognitif) dan kurang mampu menyentuh aspek pembentukan sikap (afektif) dan pembiasaan (psikomotorik).

Pada hakekatnya pendidik adalah sebagai fasilitator. Ia memfasilitasi aspek kognitif, afektif dan psikomotor. Mampu mengembangkan kemauan peserta didik, mengembangkan kondisi belajar yang relevan agar tercipta suasana belajar yang kondusif sehingga mampu belajar mandiri (self-directed learning). Guru juga harus mampu menjadikan proses pembelajaran sebagai salah satu sumber yang penting dalam kegiatan penyelidikan dengan pemahaman yang tajam (explorası). Dengan demikian, hasil pembelajaran diharapkan lebih bermakna bagi peserta didik, karena proses pembelajaran berlangsung secara alamiah dalam bentuk kegiatan peserta didik bekerja dan mengalami, bukan lagi transfer pengetahuan dari guru ke peserta didik (Suryanto: 2014). 
Metode pembelajaran yang melibatkan peserta didik secara aktif dan menggugah semangat belajar diantaranya adalah metode Quantum Teaching. Dengan metode ini sesulit apapun meteri pelajaran apabila dipelajari dalam suasana yang menyenangkan, maka pelajaran tersebut akan dipahami mudah. Sebaliknya walaupun materi pelajaran tidak terlampau sulit untuk dipelajari, namun apabila suasana belajar membosankan, tidak menarik, apalagi peserta didik belajar dibawah tekanan, maka pelajaran akan sulit dipahami. Atas dasar pemikiran tersebut, maka agar para peserta didik mudah memahami materi pelajaran, mereka harus belajar dalam suasana yang menyenangkan, penuh daya tarik, dan penuh motivasi.

Quantum Teaching mencakup petunjuk spesifik untuk menciptakan lingkungan belajar yang efektif, merancang kurikulum, menyampaikan isi, dan memudahkan proses belajar. Quantum Teaching merangkaikan yang paling baik dari yang terbaik menjadi sebuah paket multi sensori, kecerdasan, dan kontibel dengan otak, yang pada akhirnya akan mampu melejitkan kemampuan guru untuk mengilhami dan kemampuan peserta didik untuk berprestasi (Hemarcy: 2006).

\section{Konsep Pembelajaran BTQ}

Istilah "pembelajaran" berasal dari kata "belajar" (kata kerja) yang artinya berlatih, atau berusaha memperoleh kepandaian atau ilmu, atau berubah tingkah laku atau tanggapan yang disebabkan oleh pengalaman. Kata "belajar" itu sendiri berasal dari kata dasar "ajar" yang artinya petunjuk yang diberikan kepada orang supaya diketahui. Kemudian kata "belajar" itu mendapat awalan pem- dan akhiran -an yang merupakan konfiks nomina menjadi "pembelajaran" yang mempunyai arti proses, atau cara, atau menjadikan orang atau mahluk hidup belajar (Dedikbud: 2007).

Adapun istilah "pembelajaran" terkait dengan cara menjadikan orang untuk belajar. Dalam pengertian ini ada upaya untuk membelajarkan peserta didik untuk belajar, sehingga mengakibatkan peserta didik mempelajari sesuatu dengan lebih aktif, efektif dan efisien (instruksional), serta pendidik berperan 
sebagai mediator yang membimbing dan perantara dalam hubungan interaksi, fasilitator yang mengusahakan sumber belajar dan mempermudah kegiatan interaksi, motivator yang mengarahkan dan mendorong berlangsungnya tingkah laku sosial yang baik, mengembangkan gaya interaksi pribadi, dan menumbuhkan hubungan yang positif antar para pribadi (Uzer: 2011).

Ada beberapa Pendekatan pembelajaran Baca Tulis al-Qur'an meliputi:

a. Keimanan, yang mendorong peserta didik untuk mengembangkan pemahaman dan keyakinan tentang adanya Allah SWT sebagai sumber kehidupan.

b. Pengamalan, mengkondisikan peserta didik untuk mempraktekkan dan merasakan hasil-hasil pengamalan isi Al-Qur'an dalam kehidupan seharihari.

c. Pembiasaan, melaksanakan pembelajaran denga membiasakan sikap dan perilaku yang baik sesuai dengan ajaran islam yang terkandung dalam AlQur'an serta dicontohkan oleh para ulama'.

d. Rasional, usaha meningkatkan kualitas proses dan hasil pembelajaran Alqur'an denga pendekatan yang memfungsikan rasio peserta didik, sehingga is dan nilai-nilai yang ditanamkan mudah dipahami dengan penalaran.

e. Emosional, upaya menggugah perasaan (emosi) peserta didik dalam menghayati kandungan Al-Qur'an sehingga terkesan dalam jiwa peserta didik.

f. Fungsional, menyajikan materi Al-Qur'an yang memberikan manfaat nyata bagi peserta didik dalam kehidupan sehari-hari dalam arti luas.

Adapun faktor faktor Penghambat dalam Pembelajaran BTQ anatar lain:

a. Pendidik

Pendidik merupakan salah satu faktor pendidikan yang sangat penting, karena pendidik itulah yang akan bertanggung jawab dalam pembentukan pribadi anak didiknya. Terutama pendidikan agama Islam mempunyai pertanggung jawaban yang lebih berat dibandingkan dengan pendidik pada umumnya, karena selain bertanggung jawab terhadap dalam pendidikan 
atau pembinaan pribadi si anak didik, hal itu sangat berpengaruh (Dzakiyah: 2009).

b. Anak didik

Pengetahuan yang diberikan kepada anak didik melalui proses pendidikan disuatu lembaga tidak mudah dilaksanakan sesuai dengan tujuan yang dimaksud, karena disebabkan banyak perbedaan dan persamaan potensi yang dibawa anak didik. Dengan adanya perbedaan dan persamaan yang dimiliki anak didik, menyebabkan kesulitan dalam memberikan model pembelajaran yang baik dan tepat dalam proses belajar mengajar.

c. Sarana Prasarana

Dapat dikatakan bahwa semakin lengkap alat atau sarana dan prasarana yang dibutuhkan dalam pembinan Baca Tulis Al-Qur'an, maka makin mudah pendidik dan murid malaksanakan proses belajar mengajarnya. Proses belajar mengajar akan berjalan lancar apabila ditunjang sarana yang lengkap dari berbagai faktor pendukung, karena masalah fasilitas merupakan masalah yang sangat penting dalam mencapai tujuan pendidikan khususnya dalam pembelajaran Baca Tulis Al-Qur'an sarana pendidikan Islam.

\section{Pengertian Metode Quantum Teaching}

Metode Quantum Teaching pada dasarnya tidak jauh berbeda dengan metode-metode pembelajaran dalam rumpun konstruktivisme seperti active learning, contectual teaching and learning, cooperative learning dan sebagainya. Namun dalam penerapannya metode ini lebih menekankan pada upaya membangkitkan motivasi peserta didik dengan segala nuansanya. Oleh karena itu, studi tentang Quantum Teaching ini diharapkan dapat mencerminkan hakikat pembelajaran dalam dunia pendidikan, dan karenanya pula penting untuk mengetahui bagaimana metode ini diterapkan, khususnya dalam pembelajaran Baca Tulis Al-Qur'an.

Prinsip-prinsip metode Quantum Teaching Prinsip adalah kebenaran yang menjadi pokok dasar berfikir atau bertindak. Prinsip-prinsip Quantum Teaching 
adalah kebenaran yang menjadi pokok dasar berfikir atau bertindak yang mempengaruhi seluruh aspek pembelajaran, yaitu: segalanya berbicara, segalanya bertujuan, pengalaman sebelum pemberian nama, akui setiap usaha, jika layak dipelajari maka layak pula dirayakan (Dedikbud: 2007).

Adapun kerangka rancangan Pembelajaran Quantum Teaching sebagai berikut :

a. Tumbuhkan

Unsur ini berupaya untuk menumbuhkan minat peserta didik dengan memuaskan "Apakah Manfaatnya BagiKu" (Ambak), dan memanfaatkan kehidupan peserta didik dengan menyertakan diri mereka dan memikat mereka. Hal ini penting dilakukan karena penyertaan menciptakan jalinan dan kepemilikan bersama atau kemampuan saling memahami, mencari tanggapan "yes!" dan mendapatkan komitmen untuk menjelajah, serta menumbuhkan "kebutuhan untuk mengetahui". Strategi yang diperlukan antara lain: memberikan pertanyaan, melakukan pantomim, menampilkan lakon pendek dan lucu, drama, video atau cerita.

b. Alami

Unsur ini memberi pengalaman kepada peserta didik, dan memanfaatkan hasrat alami otak untuk menjelajah. Sehingga pengalaman membuat pendidik dapat mengajar "melalui pintu belakang" untuk memanfaatkan pengetahuan dan keingintahuan mereka. Strateginya adalah menciptakan atau mendatangkan pengalaman umum yang dapat dimengerti semua peserta didik, misalnya apa yang telah mereka lihat, dengar dan alami dalam kehidupan nyata. Bisa juga melalui permainan dan simulasi, tugas kelompok yang mengaktifkan pengetahuan yang sudah dimiliki peserta didik.

c. Namai

Dalam unsur penamaan dapat memuaskan hasrat alami otak untuk memberikan identitas, menpendidiktkan, dan mendefinisikan. Penamaan ini dibangun atas pengetahuan dan keingintahuan peserta didik pada saat minat memuncak sebagai sebuah masukan. Penamaan adalah saatnya 
untuk mengajarkan konsep, ketrampilan berfikir, dan strategi belajar. Strateginya adalah gunakan gambar warna, alat bantu, kertas tulis, dan poster dinding.

d. Demonstrasikan

Unsur ini memberikan kesempatan bagi peserta didik untuk menerjemahkan, mengaitkan pengalaman dengan data baru, sehingga mereka menghayati dan membuatnya sebagai pengalaman pribadi, serta mereka dapat menunjukkan bahwa "mereka tahu". Strateginya adalah melakukan sandiwara, melakukan dan atau membuat permainan, menyanyikan dan atau menggubah lagu, melakukan praktikum, melakukan diskusi dan atau presentasi, dan sebagainya.

e. Ulangi

Rekatkan gambaran keseluruhannya. Pada unsur ini peserta didik ditunjukkan tentang cara-cara mengulang materi. Pengulangan memperkuat koneksi saraf dan menumbuhkan rasa "Aku tahu bahwa aku memang tahu ini". Jadi, pengulangan harus dilakukan secara multimodalitas dan multikecerdasan, dan lebih baik dalam kontek yang berbeda dari sebelumnya. Strateginya melalui resume, peta pikiran, menggemakan dalam kontek menirukan secara bersama, pengulangan trio, presentasi dan sebagainya.

f. Rayakan

Perayaan menambatkan belajar dengan asosiasi positif, dan merupakan pengakuan atas usaha, partisipasi, pemerolehan ketrampilan dan ilmu pengetahuan. Ingat, jika layak dipelajari, maka layak pula dirayakan!. Strateginya dengan cara memberi pujian, bernyanyi bersama, applaus tepuk tangan, open house, yel-yel kelas dan sebagainya.

\section{Motivasi Belajar}

Sebelum sampai pada motivasi, maka penulis terlebih dahulu akan menjelaskan kata "motiv" terlebih dahulu, karena kata "motiv" muncul terlebih dahulu sebelum kata "motivasi'. Kedua hal tersebut merupakan daya 
upaya yang mendorong seseorang untuk melakukan sesuatu. Motiv dapat diartikan sebagai suatu kondisi internal (kesiapan, dan kesiagaan). Yang berawal dari kata "motiv" itu, maka motivasi dapat diartikan sebagai daya penggerak yang telah aktif pada saat-saat tertentu terutama apabila kebutuhan untuk mencapai tujuan sangat dirasakan mendesak.

Motivasi secara etimologi adalah dorongan atau daya penggerak yang ada daya penggerak yang berada dalam diri seseorang untuk melakukan suatu tindakan untuk mencapai sebuah tujuan.

Motivasi adalah suatu dorongan yang terdapat dalam diri seseorang, sehingga ia berusaha untuk meningkatkan kemampuannya setinggi mungkin dalam semua aktifitas untuk mencapai kualitas tugas sebaik-baiknya, dan mencapai prestasi yang terus meningkat dibandingkan sebelumnya serta lebih tinggi dibandingkan temannya (Dzajali: 2005).

Menurut Sardiman menyebutkan motif dapat diartikan sebagai daya upaya yang mendorong seseorang untuk melakukan sesuatu. Motif dapat dikatakan sebagai daya penggerak dari dalam dan di dalam subjek untuk melakukan aktifitas-aktifitas tertentu demi mencapai suatu tujuan. Bahkan motif dapat dikatakan sebagai suatu kondisi intern (kesiapsiagaan). Berawal dari kata motif itu, maka motivasi dapat diartikan sebagai daya penggerak yang telah menjadi aktif. Motif menjadi aktif pada saat-saat tertentu, terutama bila kebutuhan untuk mencapai tujuan sangat dirasakan atau mendesak.

\section{Kesimpulan}

Berdasarkan pembahasan hasil analisis data,secara umum pembelajaran quantum Teaching dapat diterapkan sesuai dengan tahapan-tahapan yang telah dirumuskan. Selain itu juga dapat meningkatkan nilai akademis, mental perilaku serta keterampilan peserta didik. Pembelajaran yang aktif, kreatif, efektif, dan menyenangkan juga dapat di wujudkan.

Pembelajaran Baca Tulis Al-Qur'an (BTQ) di SDN Watuagung Kecamatan Prigen Kabupaten Pasuruan senantiasa membutuhkan pembaharuanpembaharuan yang disebut inovasi pembelajaran. Inovasi pembelajaran 
merupakan perubahan yang baru dan secara kualitatif berbeda dari hasil sebelumnya, serta sengaja diusahakan untuk meningkatkan kualitas guna mencapai tujuan yang diharapkan.

Peran pendidik SDN Watuagung Kecamatan Prigen Kabupaten Pasuruan tidak hanya mengajar, menyampaikan atau mentransfer ilmu pengetahuan kepada murid sehingga mencapai tujuan yang diharapkan, tetapi pendidik juga mampu menjadi pendidik, pembaharu, pembimbing, teladan, pencari, penuntun, pencipta, pengilham cita-cita, pekerja keras dan cerdas, serta sebagai orang yang berani menghadapi kenyataan.

Prinsip "ivovasi tiada henti" dijadikan semangat untuk melakukan perubahan ke arah yang lebih baik." Sesungguhnya Allah tidak akan mengubah nasib suatu kaum, apabila mereka itu tidak mau berusaha mengubah nasibnya sendiri. Inilah landasan spiritual yang dipakai pengelola SDN Watuagung Kecamatan Prigen Kabupaten Pasuruan dalam inovasi dan peningkatan kualitas pembelajarannya.

Kegiatan pembelajaran adalah sebuah interaksi yang bernilai pendidikan, karenanya pembelajaran merupakan ruh dari pendidikan itu sendiri. Materi pelajaran yang pendidik berikan itu akan kurang memberikan dorongan kepada Peserta didik bila penyampaiannya menggunakan strategi yang kurang tepat. Di sinilah kehadiran metode menempati posisi penting dalam pembelajaran. Pengalaman membuktikan bahwa kegagalan pembelajaran salah satunya disebabkan oleh pemilihan metode yang kurang tepat. Kelas yang kurang bergairah dan kondisi peserta didik yang kurang kreatif dikarenakan penentuan metode yang kurang sesuai dengan karakteristik Peserta didik, sifat bahan, dan tujuan pembelajaran. Karena itu dapat dipahami bahwa metode adalah suatu cara yang memiliki nilai strategis dalam pembelajaran (Jamarah: 2009).

Metode Quantum Teaching adalah penggubahan bermacam-macam interaksi yang ada di dalam dan di sekitar momen belajar. Interaksi-interaksi ini mencakup unsur-unsur untuk belajar efektif yang mempengaruhi keberhasilan Peserta didik, mengubah kemampuan dan bakat alamiah Peserta didik menjadi cahaya yang akan bermanfaat bagi mereka sendiri dan orang lain. 
Menyikapi inovasi pembelajaran dengan Metode Quantum Teaching itu, maka Pembelajaran di SDN Watuagung kecamatan Prigen kabupaten Pasuruan khususnya mata pelajaran Baca Tulis Al-Qur'an (BTQ) menggunakan metode Quantum Teaching, dengan alasan sebagai berikut:

1. Quantum Teaching: Melibatkan Seluruh Komponen Panca Indra

Salah satu Prinsip Quantum Teaching adalah segalanya berbicara. Segalanya dari lingkungan kelas hingga gerak-gerik pendidik, dari kertas yang pendidik bagikan hingga rancangan pembelajaran mengirimkan pesan tentang belaja.

Peserta didik belajar dari apa yang mereka lihat, mereka dengar, mereka kecap, mereka baui, mereka sentuh, yang mereka lakukan, mereka bayangkan, mereka intuisikan, dan apa yang mereka rasakan. Dengan kata lain, pembelajaran harus efektif dengan melibatkan seluruh panca indera Peserta didik. Oleh karena itu penyampaian materi pembelajaran harus didasarkan pada tahap perkembangan kognitif murid dan kebutuhan murid.

2. Quantum Teaching: Strategi Pembelajaran yang Menyenangkan

Tidak kalah pentingnya bahwa pembelajaran akan efektif jika dilakukan dalam suasana yang menyenangkan, bukan sebaliknya membebani atau membuat Peserta didik menjadi bosan. Bila terjadi kesan bahwa belajar itu beban, maka hal ini akan berpengaruh pada perkembangan berikutnya.

Pada usia anak-anak, pendidik harus mampu memahami karakteristik peserta didik yang masih cenderung menyukai permainan. Suasana belajar seasyik bermain di luar kelas sangat menyenangkan peserta didik dipandang sebagai peluang bahwa pembelajaran akan lebih efektif bila dapat dikemas dengan permainan yang menyenangkan. Metode bermain yang memperhatikan kecenderuan Peserta didik ini merupakan bagian dari metode Quantum Teaching. Bentuk-bentuk permainan disesuaikan dengan topiktopik pembelajaran saat itu. Misalnya kartu lafdiyah, lacak jawab, aneka kreasi ular tangga, aksara bermakna dan lain-lain. 
3. Quantum Teaching: Strategi Pembelajaran yang Bermakna

Agar pembelajaran lebih bermakna, maka pembelajaran harus diikuti dengan bentuk-bentuk penerapannya dalam kehidupan sehari-hari. Misalnya pembelajaran tentang membaca al-Qur'an, maka disediakan di masingmasing kelas dan ruang kitab suci al-Qur'an untuk dibaca sebelum memulai pelajaran dan pekerjaan. Pembelajaran tentang shalat berjamaah, maka disediakan musholla untuk melaksanakan praktik shalat Duha, Dluhur dan Jum'at, sehingga peserta didik mampu menerapkan amaliah ibadahnya dalam kehidupan sehari-harinya. Pembelajaran tentang infaq dan shadaqah, maka disediakan kesempatan bagi Peserta didik untuk mengaplikasikannya melalui infaq jariah setiap hari Jum'at, pelaksanaan zakat fitrah dan zakat mal setiap bulan Ramadhan, dan berlatih berqurban, sehingga Peserta didik terbiasa mengaktualisasikan nilai-nilai Al-Qur'an dalam jiwanya dan kehidupannya. Dalam pembelajaran Quantum Teaching mensyaratkan tujuan pembelajaran Baca Tulis Al-Qur'an (BTQ) dikaitkan dengan amaliah kehidupan sehari-hari, sehingga pembelajaran lebih bermakna, yang dikaitkan dengan AMBAK ( $\boldsymbol{A p a}$ Manfaatnya $\boldsymbol{B A g i - K}$ ).

Dalam pelaksanaan pembelajaran Baca Tulis Al-Qur'an (BTQ) dengan metode Quantum Teaching, maka pendidik lebih cermat menyusun rencana beberapa tahap persiapan dan perencanaan pembelajaran TANDUR (Tumbuhkan, Alami, Namai, Demonstrasikan, Ulangi, dan Rayakan).

Demikian juga dalam menerapkan metode Quantum Teaching dalam pembelajaran Baca Tulis Al-Qur'an (BTQ) maka seorang pendidik harus merencanakan langkah-langkah pembelajaran yang dilakukan sebagai berikut.

\section{Langkah 1: Tumbuhkan}

- Setelah salam pembuka yang dikombinasikan dengan pekik quantum, pendidik berusaha menarik minat Peserta didik dengan cerita keutamaan waktu atau masa. 
- Pendidik memotivasi Peserta didik dengan tujuan pembelajaran, sehingga pembelajaran menjadi bermakna bagi peserta didik dalam kehidupan sehari-hari

\section{Langkah 2: Alami}

- Peserta didik menyampaikan pengalaman atau pengetahuannya tentang memanfaatkan waktu sehari-hari.

- Peserta didik melafadzkan surat Al-Ashr, baik dalam kelompok kecil maupun kelompok besar secara bergilir dan bersama-sama

- Peserta didik diberi kesempatan untuk menerjemah surat Al-Ashr, baik ayat perayat maupun potongan-potongan ayat.

- Peserta didik diberi kesempatan untuk meyalin surat Al-Ashr secara mandiri dengan dipandu oleh pendidik.

\section{Langkah 3: Namai}

- Setelah Peserta didik mengalami dan mengkonstruksi sendiri pengetahuan-pengetahuannya, pendidik menggaris bawahi dan menyampurnakan pengetahuan peserta didik

- Pendidik memperkenalkan pada peserta didik cara mudah menerjemah ayat demi ayat dengan penguasaan VAK (Visual, Auditorial dan Kinestetik) kemudian ditirukan oleh seluruh peserta didik

- Pendidik menjelaskan cara mudah menulis ayat dengan huruf hijaiyah melalui penguasaan VAK

\section{Langkah 4: Demonstrasikan}

- Peserta didik mempraktikkan cara mudah menerjemah ayat demi ayat Surat Al-Ashr dan ditirukan oleh seluruh Peserta didik di bawah panduan pendidik.

- Peserta didik mempraktikkan cara mudah menulis ayat secara mandiri ayat demi ayat Surat Al-Ashr.

- Peserta didik mempraktikkan cara menggunakan kartu lafdiyah secara mandiri dengan kelompok yang ditentukan pendidik. 


\section{Langkah 5: Ulangi}

- Untuk memastikan kemampuan yang dimiliki Peserta didik tentang menerjemah dan menyalin ayat Surat Al-Ashr, pendidik mengadakan tanya jawab tentang makna lafdiah kepada seluruh Peserta didik secara bergiliran.

- Kemudian menugaskan peserta didik untuk menyalin secara imlak potongan-potongan ayat Surat Al-Ashr,

- Pendidik menugaskan peserta didik membuat media "Kartu Lafdiyah" Surat Al-Ashr sebagai alat untuk latihan/belajar di rumah.

\section{Langkah 6: Rayakan}

- ternyata dalam waktu yang relatif singkat, peserta didik dapat mengikuti pembelajaran dengan semangat dan hasil yang cukup menggembirakan, pendidik memberikan applaus bersama-sama dan poin unggulan bagi peserta didik yang mendapat nilai antara 9-10 sebagai penghargaan.

- Dilanjutkan dengan menyanyi bersama-sama lagu "Terima Kasih Allah", (Teks Lagu, lampiran 2) diakhiri dengan Alhamdulillah kemudian salam.

\section{b. Metode Quantum Teaching Dapat Meningkatkan Motivasi belajar} Baca Tulis Al-Qur'an (BTQ) di SDN Watuagung Kecamatan Prigen Kabupaten Pasuruan.

1. Quantum Teaching meningkatkan Motivasi Belajar

Pada bagian ini secara spesifik akan dideskripsikan peningakatan motivasi dan prestasi peserta didik dalam pembelajaran Baca Tulis Al-Qur'an (BTQ) dengan menggunakan metode Quantum Teaching.

Pengenalan tentang metode ini diawali dengan membuat peserta didik merasa nyaman dan senang dalam kegiatan pembelajaran. Hal ini dapat dibuktikan dalam langkah-langkah pembelajaran Quantum Teaching sebagai berikut.

Pada langkah TUMBUHKAN. Suasana pembelajaran nampak kodusif dan menggairahkan. Mereka bersama-sama meneriakkan "Pekik Quantum" yang dipandu oleh Guru: menyatukan visi, diucapkan dengan lisan dan 
diaktualisasikan dengan tingkah laku. "Aku mau (tangan kanan mereka menempel pada dada), aku tahu (tangan kanan mereka memegang dahi) dan aku mampu (tangan kanan mereka mengepal kuat kearah depan dan menghunjam bumi)". Serta mereka menyadari akan pentingnya materi sesuai tujuan pembelajaran, setelah mengetahui AMBAK (Apa Manfaatnya $B A g i-K u)$ dalam kehidupan mereka. Demikian juga dengan pertanyaan pembuka Quantum, peserta didik bersama guru bersuka ria dan bersemangat memulai pembelajaran. 


\section{DAFTAR PUSTAKA}

Daradjad. Zakiah. 2011. Metode Khusus Pengajaran Agama Islam. Jakarta: Pustaka Antara, 2011.

Departemen Agama RI. 2007. Kurikulum dan Hasil Belajar Quran Hadits Madrasah Ibtidaiyah. Jakarta: Dirjen Kelembagaan Agama Islam.

DePorter, Bobbi dan Mike Hernacki. Quantum Learning: Membiasakan Belajar Nyaman dan Menyenangkan. Bandung: Mizan Media Utama, 2006.

Djaali. 2005. Psikologi Pendidikan. Jakarta: Program Pascasarjana Universitas Negeri Jakarta.

Halim. Abd. 2005. Pembelajaran Quran hadist dengan metode Quantum Teaching. Malang: PPs Universitas Muhammadiyah.

Moleong, Lexy. Metodologi Penelitian Kualitatif. Bandung: Remaja Rosdakarya, 2007.

Rakhman. 2007. Kurikulum Muatan Lokal mata palajaran Baca Tulis Al-Qur'an tingkat SD/MI. Pemerintah Kabupaten Pasuruan: Dinas Pendidikan.

Suyanto. 2014. Panduan Pembelajaran Berbasis Ramah Anak. Malang: Plan Indonesia. 